National Science Foundation (NSF). The students. Stephen and Annette Waylett, spent the 1983 Antarctic winter at Palmer Station, Antarctica, gathering data on atmospheric chlorofluorocarbons, ozone, carbon dioxide, methane and nitrous oxide, together with supporting meteorological observations. The data were to have been included in master's degree dissertations.

Stephen Waylett had already failed one essential course for his degree and had not completed another when the couple left, although both difficulties could have been rectified later, according to a former supervisor.

The couple did supply the university with weekly averages of measurements during the period of observations, so there seems little doubt that measurements were correctly made. The university contends that, as the intermediary which paid for the research, it owns the data. University officials say they have offered to let the couple keep a copy of the data and that the Wayletts' research contribution would be acknowledged in any future use of it.
NSF's legal department says it knows of no previous instance of a researcher refusing to release data gathered under a foundation grant. The grant conditions do not apparently specify who formally owns data gathered; that they will be made public is simply presumed.

NSF has said it will stay out of the dispute between the university and the Wayletts, at least until the final report from the $\$ 600,000$ research project falls due next summer. Although final reports are often fairly brief, the university will need the Wayletts' data, which represent year two of a four-year series, for statistical comparisons, according to the project's principal investigator.

Those who know the Wayletts are at a loss to account for their behaviour, although they did apparently have some complaints about their tuition. The couple's whereabouts, and that of the data, are now unknown. A temporary restraining order issued by a federal court judge forbidding the couple to destroy or damage the data has still not been served after two weeks.

Tim Beardsley

\section{Framatome joins the fold}

Framatome, the French nuclear company which is the largest constructor of nuclear reactors outside the United States, has been taken over by a French nationalized group, the Compagnie Générale Eléctrique (CGE), a move that given the French state essentially total control of the nation's nuclear industry.

Framatome not only constructs the nuclear component of French pressurized water reactors (PWRs), but has an affiliate Novatome, the constructor of the French fast breeder Superphenix. CGE itself controls both Alsthom Atlantique which makes the turbogenerators for the reactors and Câbles de Lyon which provides the electrical cabling. Moreover, the civil engineers Dumez, involved in the construction of the buildings for many French power stations, is to become a minority (10 per cent) shareholder in Framatome, and the national atomic energy authority, the Commissariat á l'Energie Atomique (CEA), will take 35 per cent. CGE will be the leading shareholder with $\mathbf{4 0}$ per cent, the national electricity utility Eléctricité de France (EDF) will take 10 per cent "to see the bills", and Framatome staff will have the remaining 5 per cent.

The reconstruction of Framatome was necessary because of the collapse last year of Creusot-Loire, the private French steel giant, which held 50 per cent of Framatome (CEA had the other $\mathbf{5 0}$ per cent), and which the French government refused to bail out. This led to long discussions over the future of Framatome, clouded by the end of major purchasing of PWRs by EDF. For EDF, Framatome expects to be constructing four nuclear systems (pressure vessels and associated steam generators) next year, but only two in 1987 , two in 1988, two in 1989 and then one a year.

Orders may pick up during the late first PWRs (which went on line in the mid1970s), but meanwhile the company must either rely on the slack export market or diversify. Profits are expected to amount to FF 800 million ( $£ 7$ million) over the next four years, but are somewhat unpredictable thereafter. Diversification into computer software and desalinization had begun before the takeover, but the size of the CGE group (second only to Renault in France) should now simplify redeployment of the 7,600 Framatome staff.

Framatome may also be better placed to compete for the few nuclear contracts now available abroad. Framatome has feared that competitors would be able to exploit - and were exploiting - its anomalous position after the Creusot-Loire collapse. But there must be doubt as to whether the now monolithic structure of the French nuclear enterprise will prove an asset or a hindrance.

In the past, governments and utilities have tended to diversify risks by placing orders for differenct parts of a power station (nuclear, conventional, civil) with different companies and even different countries, and it is pointed out in France that the almost equally monolithic German nuclear constructor, Kraftwerk Union, has not had an export order since 1975. In France, however, the now closer government ties with nuclear construction although always close before - may not harm export prospects in what was always a highly politicized market.

Robert Walgate 1990s, when EDF will want to replace its
Sakharov

\section{Does no news mean bad news?}

DR Andrei Sakharov may have been taken from his Gor'kii apartment to an unknown destination, a former Soviet dissident, the writer Lev Kopelev, claimed last week. Kopelev, who now lives in West Germany, told correspondents that the duty policeman who had been constantly stationed outside the Gor'kii apartment block in which Sakharov has been held had been removed in mid-August. When questioned by Dr Efrem Yankelevich, Sakharov's stepson-in-law and his representative abroad, Kopelev said that a recent visitor to Moscow had been told of it by a dissident source.

The last definite news of either Sakharov or his wife Elena Bonner was a postcard from the latter dated 4 July. This postcard, and one dated 29 June, broke an enforced silence of more than two months, during which, judging from the numbering of the postcards, 28 cards had been posted only to disappear en route. In both these cards, Mrs Bonner traced over the pronoun "Ya" (I) and the verbal endings indicating the first person singular, presumably to contrast, by implication, her condition ("I feel, physically, in good shape") with that of her husband, who at that time was on hunger strike in hospital.

At the end of June, the West German newspaper Bild came into possession of two videotapes showing Sakharov as a patient in the Semashko Hospital in Gor'kii, in which, inter alia, Sakharov was shown reading Western scientific articles and news magazines whose dates suggest that Sakharov was still alive in mid-June. A further video released through Bild indicated that Sakharov was discharged from the hospital on 11 July, but, says Dr Yankelevich, the evidence for the date was, in this case, only a notice on the hospital wall. According to the commentary, the Bild tapes were made specifically to refute Western fears that Sakharov was being medically mistreated.

Such reassurances were probably associated with the then impending tenth anniversary of the $\mathrm{H}-$ lsinki Final Act on 1 August, and with the decision of the Soviet authorities, relayed to US Senator Paul Simon through the president of the Soviet Academy of Sciences, Dr Anatolii Aleksandrov, that it would be a violation of the Non-Proliferation Treaty to let Sakharov go abroad, since he could disclose atomic secrets to other governments and private organizations, "including terrorist groups".

If, indeed, the story of the vanishing policeman is true, and the Sakharovs have, indeed, been removed from Gor'kii, then the palliative was only temporary, and new fears for the couple's safety may well be justified. Vera Rich 